\title{
Depositional, diagenetic and stratigraphic aspects of Macaé Group carbonates (Albian): example from an oilfield from Campos Basin
}

\author{
Aspectos deposicionais, diagenéticos e estratigráficos em \\ carbonatos do Grupo Macaé (Albiano): exemplo de campo petrolífero \\ da Bacia de Campos
}

\author{
Juliana Okubo ${ }^{1 *}$, Ricardo Lykawka², Lucas Veríssimo Warren ${ }^{3}$, \\ Julia Favoretoํ․ Dimas Dias-Brito ${ }^{3}$
}

\begin{abstract}
Carbonate rocks from the Macaé Group (Albian) represent an example of carbonate sedimentation related to the drift phase in Campos Basin. This study presents depositional features, integrating them with diagenetic and stratigraphic aspects of the Macaé Group carbonates including the upper part of the Quissamá Formation and the lower part of the Outeiro Formation. Macroscopic analyses in cores and microscopic ones in thin sections allowed the recognition of eleven sedimentary facies - nine of them corresponding to the Quissamã Formation and two of them representing the Outeiro Formation. These facies were grouped into five facies associations. Oolitic grainstones and oncolitic grainstones are interpreted to be deposited in shallow depth probably in shoals above the fair weather wave base. The interbanks between shoals were formed in less agitated waters and characterized by deposition of peloidal bioclastic packstones and wackestones representative of sedimentation in calm waters. Bioclastic packstones and oolitic packstones/wackestones represent allochthonous deposits related to the beginning of the regional drowning that occur in upper Quissamã Formation. Pithonellids wackestones and bioclastic wackestones with glauconite are related to deep water deposits, characteristics of the Outeiro Formation. Post-depositional features revealed the action of diagenetic processes as, micritization, cimentation, dissolution, compaction, dolomitization and recrystallization occurred during the eoand mesodiagenesis phases. Vertical facies analysis suggests shallowing upward cycles stacked in a sequence progressively deeper towards the top (from the Quissamã Formation to the Outeiro Formation).
\end{abstract}

KEYWORDS: Carbonate Rocks; Quissamã Formation; Outeiro Formation; Facies; Diagenesis.

\begin{abstract}
RESUMO: As rochas carbonáticas do Grupo Macaé (Albiano) representam a sedimentaçáo carbonática relacionada ao início da fase drifte na Bacia de Campos. Discutem-se aqui aspectos deposicionais, diagenéticos e estratigráficos das rochas carbonáticas do Grupo Macaé, englobando a porção superior da Formação Quissamã e a porção basal da Formação Outeiro. Análises macroscópicas em testemunhos e microscópicas utilizando-se laminas delgadas permitiram o reconhecimento de onze fácies sedimentares - nove delas correspondentes à Formação Quissamã e duas à Formação Outeiro. Estas foram agrupadas em cinco associaçōes de fácies, relacionadas às diferentes posiçôes fisiográficas de uma plataforma carbonática. Os bancos carbonáticos estäo relacionados à deposiçãa de grainstones oolíticos e grainstones oncolíticos em profundidades rasas, acima do nivel de base de ondas de tempo bom (NBTOB). Os baixios oncoliticos ou interbancos foram formados em águas menos agitadas e são caracterizadas pela deposiçāo de packstones peloidais bioclásticos e wackestones, representativos da sedimentação em águas calmas Packstones bioclásticos e wackestone/packstones ooliticos representam depósitos alóctones relacionados ao início do afogamento regional da plataforma que ocorre na porção superior da Formação Quissamã. Wackestones com pitonelídeos e wackestones bioclásticos com glauconita são aqui relacionados a depósitos de água profunda, característicos da Formação Outeiro. As feiçōes pós-deposicionais revelaram a atuação de processos diagenéticos de micritização, cimentação, dissolução, compactação, dolomitização e recristalização, ocorridos nas fases eo-e mesodiagenética. A análise da sucessão vertical das fácies indica a presença de diversos ciclos de raseamento ascendente, empilhados com uma tendência retrogradacional da sequência em direção ao topo (passagem da Fm. Quissamá para Fm. Outeiro).
\end{abstract}

PALAVRAS-CHAVE: Rochas Carbonáticas; Formaçāo Quissamā; Formação Outeiro; Fácies; Diagênese.

\footnotetext{
${ }^{1}$ Programa de Pós-Graduação em Geologia Regional, Instituto de Geociências e Ciências Exatas, Universidade Estadual Paulista - UNESP, Rio Claro (SP), Brasil. E-mails: juokubo@rc.unesp.br; juliafavoreto@yahoo.com.br

2Petrobras, Rio de Janeiro (RJ), Brasil. E-mail: rlykawka@petrobras.com.br

${ }^{3}$ Departamento de Geologia Aplicada, Instituto de Geociências e Ciências Exatas, Universidade Estadual Paulista - UNESP, Rio Claro (SP), Brasil. E-mails:warren@rc.unesp.br; dimasdb@rc.unesp.br

*Corresponding author.
}

Manuscript ID: 30222. Received: 01/13/2015. Approved: 05/04/2015. 


\section{INTRODUCTION}

During Albian Age, large carbonate sedimentation platform began to form along the eastern coast of Brazil and western coast of Africa, resulting from the Gondawanaland break-up and the South Atlantic opening (Ojeda 1982). In Campos Basin, this carbonate sedimentation is represented by the Quissamá and Outeiro formations, respectively proximal and distal successions (Esteves et al. 1987).

Previous studies on the same stratigraphic interval were carried out by several authors, some of them focused on the regional characterization of the Quissamá Formation (Falkenhein et al. 1981, Guardado et al.1989), while others have specifically centered on the dynamic of the oil producing fields (Franz 1987, Spadini 1992, Guimarães 1994). Here, we present the depositional aspects of the Quissamã and Outeiro formations based on the detailed description of drill cores and analysis of petrographic facies and microfacies, integrating with diagenetic features of the rock succession. The study area is located in the southwestern portion of the Campos Basin (Fig. 1), covering lithostratigraphically, the upper portion of Quissamã Formation and the basal portion of the Outeiro Formation.

\section{GEOLOGICAL CONTEXT}

The origin and evolution of Campos Basin is related to the Gondwana breakup (Eocretaceous) and is marked by the breakup of South America and Africa plates with the subsequent formation of South Atlantic Ocean (Ojeda 1982, Dias et al. 1990, Milani et al. 2000).

The tectono-sedimentary evolution of this basin occurred in three phases: rift, posrift and drift, that corresponds, respectively, to continental, transitional and marine supersequences (Dias et al. 1990, Ponte \& Asmus 2004, Winter et al. 2007). The continental sequence (Neocomian-Eoaptian) was deposited during the mechanical subsidence from the rift phase and includes the basalts of the Cabiúnas Formation and continental sediments of the Lagoa Feia Formation.

The transitional sequence (Neoaptian) is characterized by the evaporites of the Retiro Formation deposited in a

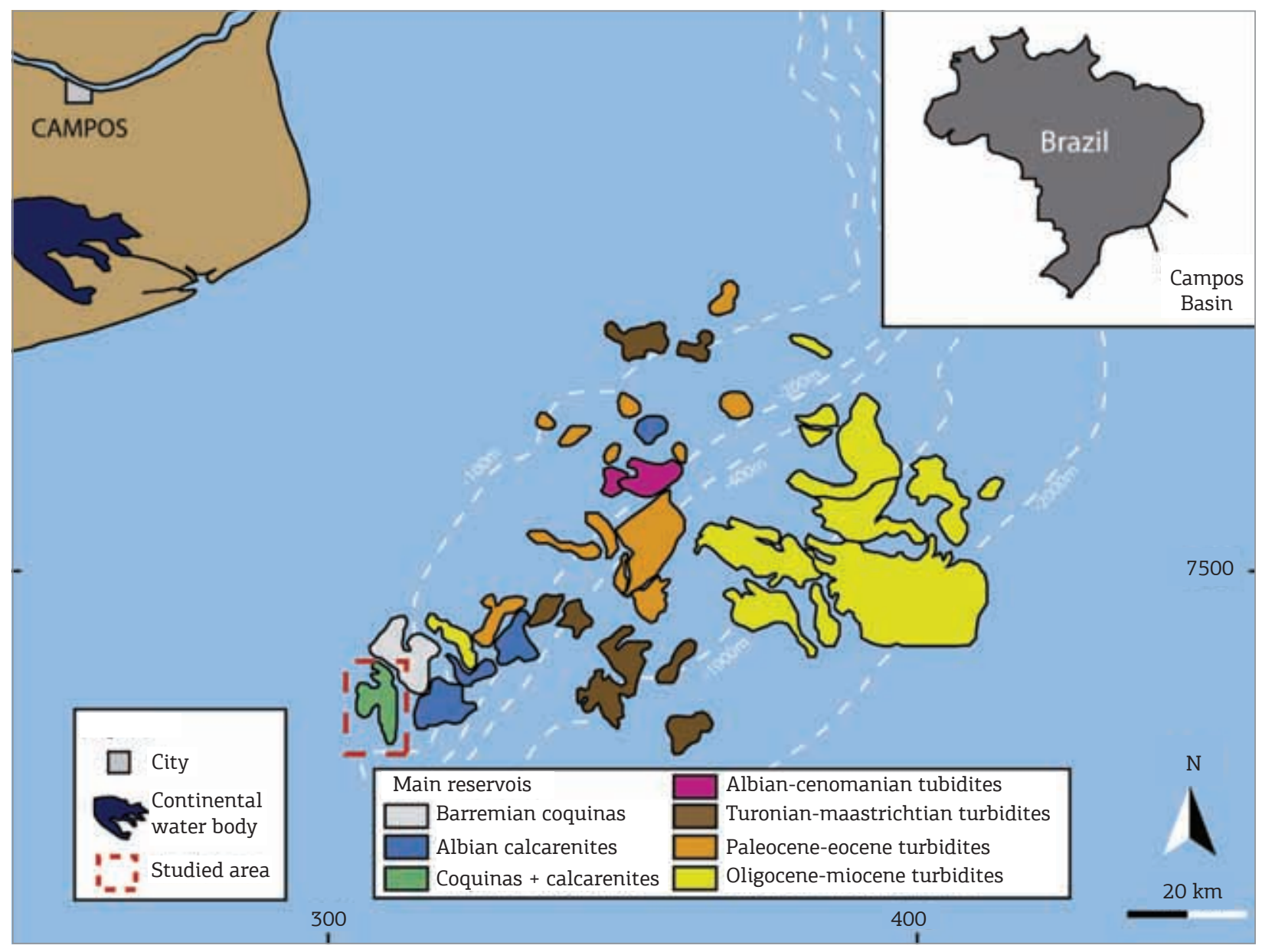

Figure 1. Location map of the studied area in southwestern portion of Campos Basin (modified from Bruhn et al. 2003) 
period of shallow marine transgression pulses over continental areas and relative tectonic quiescence (Dias et al. 1990).

The marine sequence (Albian-Recent) marks the beginning of the open marine deposition during thermal subsidence associated with the drift phase. This stage begins with carbonate sedimentation (Macaé Group) and grade to a mainly siliciclastic succession (Campos Group) affected by intense halokinesis (Winter et al. 2007).

The Macaé Group sedimentation occured during Albian Age in early drift context and comprises the Goitacás, Quissamá, Outeiro, Imbetiba and Namorado formations (Fig. 2).

The Quissamã Formation is formed by grainstones and packstones, constituted by oncoids, ooids, peloids and diverse bioclasts, associated with NE shoals (Guardado et al. 1989) deposited in high to moderate energy environment. The Outeiro Formation is composed of fine carbonate layers, interbedded with marl and shale, deposited in response to a gradual rise in sea level and the drowning of the shallow carbonate platform of the Quissamã Formation. These carbonate rocks have abundant content of pelagic microfossils, like calcispheres (pitonellids), planctonic foraminífera and radiolarians (Dias-Brito 1982).

\section{MATERIALS AND METHODS}

This study is based on macroscopic descriptions of eleven core wells and petrography analysis of 237 thin sections. Two of the eleven wells cores are continuous (A3 and A10) and have a length of about 100 to 150 meters, respectively, covering the whole studied interval, i.e., the upper part of Quissamã Formation and basal portion of Outeiro Formation.
Macroscopic analysis was carried out with the support of microscopic analysis, and focused on the detailed description of bedding, texture, faunal (bioclastic) content and diagenetic features. Rock names followed the classifications of Dunham (1962) and Embry and Klovan (1961) and facies were grouped in facies association according the Walker (1992) protocol. Cyclic analysis of the stratigraphic succession was based on the subdivision of metric swallowing upward cycles defined at the base and at the top by transgressive surfaces (Pratt et al. 1992). The differences between the sedimentary facies and the thickness of the cycles define the succession architecture (agradational, retrogradational or progradational).

\section{FACIES AND FACIES ASSOCIATION}

The sedimentary facies defined for Quissamã and Outeiro formations are shown in Tab. 1 and illustrated in Figs. 3 to 6. The facies were grouped into five facies associations (FA), which are: oncolitic-oolitic shoals (FA1), oncolitic shallows/ interbanks (FA2), protected marine (FA3), reworked deposits/allochthonous (FA4) and deep water (FA5).

The facies code used in this work is composed by the first three capital letters, in which the abbreviation represent the textural rock types of carbonate rocks, followed by three lowercase letters that representing the most abundant constituent (ooids-ool, oncoids-onc, peloids-pel, etc.).

\section{Oncolitic-oolitic shoals (FA1)}

This facies association is predominantly composed of oncolitic grainstones (GST onc), followed by oolitic

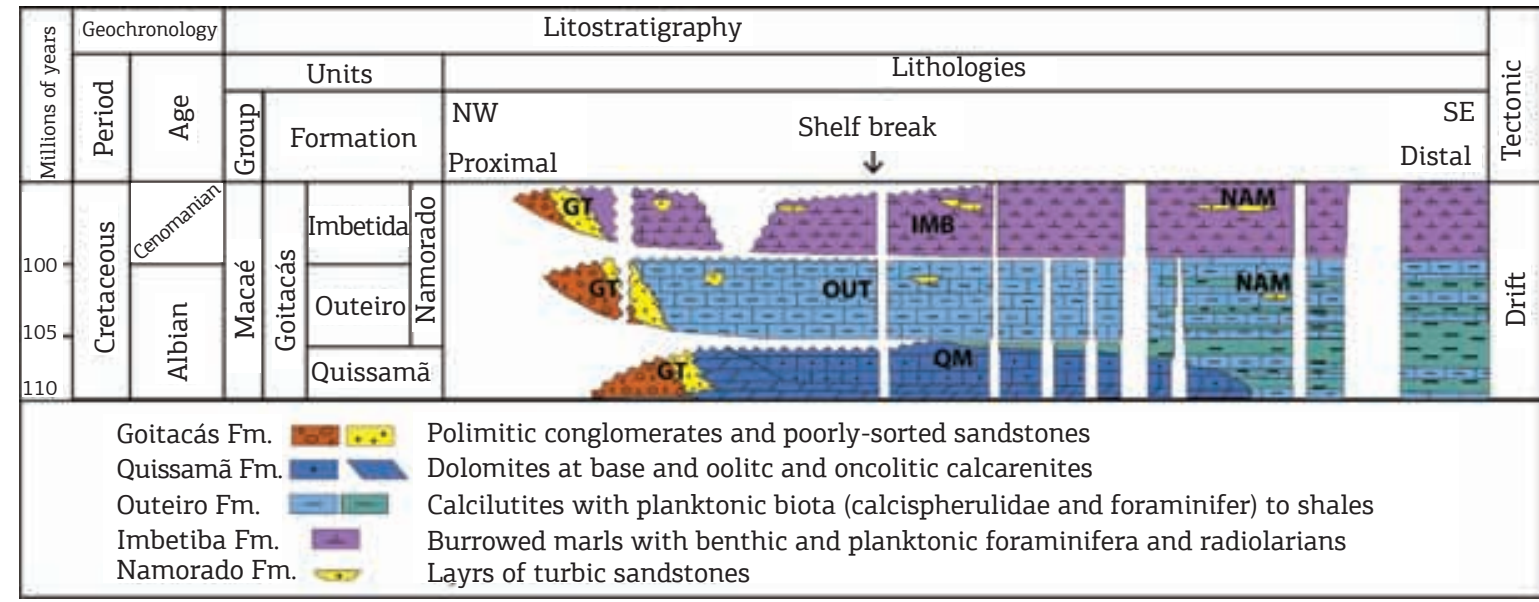

GT: Goitacás Formation, QM: Quissamã Formation; OUT: Outeiro Formation; IMB: Imbetiba Formation; NAM: Namorado Formation.

Figure 2. Stratigraphic chart of the Albian section in the Campos Basin (Winter et al. 2007) 
Table 1. Sedimentary facies of the Quissamã and the Outeiro formations

\begin{tabular}{|c|c|c|c|}
\hline Code & Facies & Description & Process \\
\hline GST ool & $\begin{array}{l}\text { Oolitic } \\
\text { grainstone }\end{array}$ & $\begin{array}{l}\text { Composed of ooids well-sorted ( } 300 \text { to } 500 \mu \mathrm{m}) \text {, peloids ( } 100 \text { to } \\
200 \mu \mathrm{m}) \text { and aggregate grains }(1 \mathrm{~mm}) \text {, showing partial to total } \\
\text { micritization. Two cementation phases: acicular fringe, which } \\
\text { keeps open the framework during eodiagenesis, and mosaic, } \\
\text { which obliterates almost all intergranular pores. }\end{array}$ & $\begin{array}{l}\text { Oscillatory subaqueous } \\
\text { flow associated with } \\
\text { reworking by fair weather } \\
\text { wave good orbitals }\end{array}$ \\
\hline GST onc & $\begin{array}{l}\text { Oncolitic } \\
\text { grainstone }\end{array}$ & $\begin{array}{l}\text { Composed of oncoids well-rounded and well-sorted, from } 500 \\
\text { to } 700 \mu \mathrm{m} \text {, whose cores are composed of echinoids and benthic } \\
\text { foraminifera. It also occurs aggregate grains, ooids, peloids and } \\
\text { rare bioclasts. Acicular cement, locally dissolved or detached do } \\
\text { grão (mechanical compaction). Pores enlarged by dissolution, } \\
\text { sometimes creating vugs. }\end{array}$ & $\begin{array}{l}\text { Oscillatory subaqueous flow } \\
\text { associated with reworking } \\
\text { by fair weather wave good } \\
\text { orbitals. The encapsulation } \\
\text { of bioclasts occurs because } \\
\text { cyanobacteria films activity. }\end{array}$ \\
\hline GST onc pel & $\begin{array}{l}\text { Oncolitic } \\
\text { peloidal } \\
\text { grainstone }\end{array}$ & $\begin{array}{l}\text { Composed of coarse portion ( }>2 \mathrm{~mm} \text { ), which contains } \\
\text { subrounded to irregular aggregate grains, produced by oncoids } \\
\text { agglutination; and medium/fine portion ( }(100 \text { to } 200 \mu \mathrm{m}) \text {, } \\
\text { composed of peloids, mollusk fragments }(<500 \mu \mathrm{m}) \text { and rare } \\
\text { benthic hyaline foraminifera. The edges of oncoids and bioclasts } \\
\text { are micritized. Pores enlarged by dissolution or filled by a drusy } \\
\text { mosaic/granular cement. }\end{array}$ & $\begin{array}{l}\text { Oscillatory subaqueous } \\
\text { flow associated with } \\
\text { reworking by fair weather } \\
\text { wave good orbitals in } \\
\text { protected environment. } \\
\text { The encapsulation of } \\
\text { bioclasts occurs because } \\
\text { cyanobacteria films activity. }\end{array}$ \\
\hline PCK onc bio & $\begin{array}{r}\text { Oncolitic } \\
\text { bioclastic } \\
\text { packstone }\end{array}$ & $\begin{array}{l}\text { Composed of oncoids }(500 \mu \mathrm{m}) \text {, microncoids e peloids }(100 \mu \mathrm{m}) \text {, } \\
\text { echinoids and benthic hyaline foraminifera in a micritic matrix. } \\
\text { Echinoids showing syntaxial overgrowth. }\end{array}$ & $\begin{array}{l}\text { Oscillatory subaqueous flow } \\
\text { associated with reworking } \\
\text { by fair weather wave } \\
\text { good orbitals in protected } \\
\text { environment. Intercalation } \\
\text { with decantation periods. }\end{array}$ \\
\hline PCK pel bio & $\begin{array}{l}\text { Peloidal } \\
\text { bioclastic } \\
\text { packstone }\end{array}$ & $\begin{array}{c}\text { Composed of oncoids }(500 \mu \mathrm{m}) \text {, microncoids e peloids }(100 \mu \mathrm{m}) \text {, } \\
\text { echinoids and benthic hyaline foraminifera dispersed in matrix. } \\
\text { Echinoids showing syntaxial overgrowth. Dissolution creates } \\
\text { bioclasts molds and enlarges pores. }\end{array}$ & $\begin{array}{l}\text { Oscillatory subaqueous flow } \\
\text { associated with reworking } \\
\text { by fair weather wave } \\
\text { good orbitals in protected } \\
\text { environment. Intercalation } \\
\text { with decantation periods. }\end{array}$ \\
\hline PCK bio & $\begin{array}{l}\text { Bioclastic } \\
\text { packstone }\end{array}$ & $\begin{array}{l}\text { Fragments }(>2 \mathrm{~mm}) \text { of mollusks, echinoids, benthic } \\
\text { agglutinated and hyaline foraminifera dispersed in a micritic } \\
\text { matrix. Pithonelids, planctonic foraminifera and opaque } \\
\text { minerals are rare. }\end{array}$ & $\begin{array}{l}\text { Rip currents in storm } \\
\text { events/ Episodic gravity flow }\end{array}$ \\
\hline WCK/PCK ool & $\begin{array}{l}\text { Oolitic } \\
\text { wackestone/ } \\
\text { packstone }\end{array}$ & $\begin{array}{l}\text { Ooids }(500 \mu \mathrm{m}) \text { and red algae }(1 \mathrm{~mm}) \text { dispersed in carbonate } \\
\text { matrix rich in pelagic elements (pithonelids as Pithonella } \\
\text { sphaerica, planctonic foraminifera as Favusella washitensis e } \\
\text { Hedbergella sp.) and echinoids fragments. }\end{array}$ & $\begin{array}{l}\text { Rip currents in storm } \\
\text { events/ Episodic gravity flow }\end{array}$ \\
\hline WCK & Wackestone & $\begin{array}{l}\text { Mostly composed of matrix, containing bioclasts (pithonelids and } \\
\text { echinoids) and sometimes euhedral dolomite crystals. }\end{array}$ & Subaqueous decantation \\
\hline WCK pit & $\begin{array}{l}\text { Pithonelid } \\
\text { wackestone }\end{array}$ & $\begin{array}{l}\text { Mostly composed of matrix, containing pithonelids (Pithonella } \\
\text { sphaerica e P. ovalis) and radiolarians. Benthic and planktonic } \\
\text { foraminifera, echinoids fragments are rare. It occurs } \\
\text { framboidal pyrites. }\end{array}$ & Subaqueous decantation \\
\hline WCK bio & $\begin{array}{l}\text { Bioclastic } \\
\text { wackestone } \\
\text { with } \\
\text { glauconite }\end{array}$ & $\begin{array}{l}\text { Mostly composed of matrix, containing angular detrital quartz } \\
\text { grains, rounded glauconite grains, echinoids and rare pithonelids. }\end{array}$ & $\begin{array}{l}\text { Subaqueous decantation } \\
\text { associated with very low } \\
\text { sedimentation rate }\end{array}$ \\
\hline DOL & Dolomite & $\begin{array}{l}\text { Brownish to gray dolomite, which are composed of euhedral } \\
\text { dolomite crystals }(100 \mu \mathrm{m}) \text {. }\end{array}$ & - \\
\hline
\end{tabular}

GST ool: oolitic grainstone; GST onc: oncolitic grainstone; GST onc pel: oncolitic peloidal grainstone; PCK onc bio: oncolitic bioclastic packstone; PCK pel bio: peloidal bioclastic packstone; PCK bio: bioclastic packstone; WCK/PCK ool: oolitic wackestone/packstone; WCK: wackestone; WCK pit: pithonelid wackestone; WCK bio: bioclastic wackestone with glauconite; DOL: dolomite. 
grainstones (GST ool). Both facies are grain-supported, wellsorted, with good roundness, high sphericity and spherical to ellipsoidal grains (Figs. 3A, 3B, 4A and 4B).

Rare bioclasts and rare micrite content suggest that these facies have been formed in agitated water, possibly under the constant action of the fair weather wave's orbitals. High-energy environments are responsible for the intense fragmentation of bioclasts by wave action and represent a stressful environment for certain organisms. Moreover, highenergy environments are more favorable to ooid formation
(Fig. 4A), by the oscillatory flow produced by fair weather wave orbitals in shallow depths.

\section{Oncolitic shallows or interbanks (FA2)}

This facies association is predominantly composed of oncolitic peloidal grainstones (GST onc pel), followed by oncolitic bioclastic packstones (PCK onc bio), which are illustrated in Figures 3C and 3D. In these facies, the hydrodynamic energy was high enough to keep moving the bioclasts and peloids (Dahanayake 1978). The core of aggregate
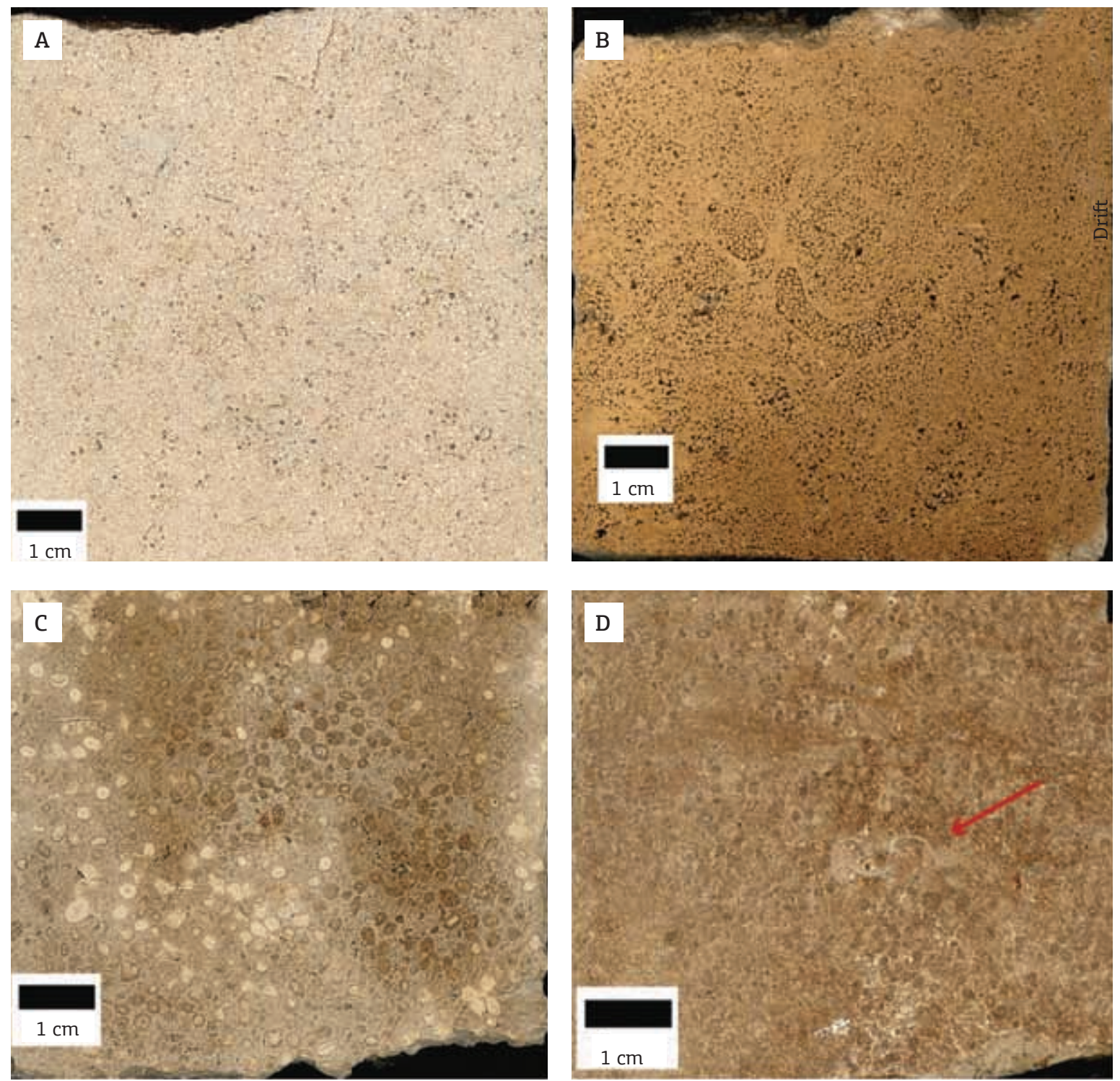

Figure 3. Facies corresponding to FA1 (A and B) and FA2 (C and D). (A) oolitic grainstone with aggregate grains, massive structure and gray color given by the cementation; (B) oncolitic grainstone, showing massive to mottled structure with probably burrowing filled by sediment; $(C)$ oncolitic peloidal grainstone, showing bimodal particle size, partially filled by cement; (D) oncolitic bioclastic packstone, showing brownish color, mottled structure and macroscopically visible bioclasts (red arrow) 
grains and oncoids (Figs. 4C and 4D) are often composed by peloids. However, it does not produce agitation and turbulence enough to trigger the formation of ooids (Simone 1980). Thus, we interpret that these facies were generated from the subaqueous flows with less intense or frequent water agitation, wherein the fair weather wave orbitals do not have enough energy to rework the bottom sediments constantly. This sedimentation conditions are consistent with protected areas between oolitic shoals and oncolitic shallows.

\section{Marine facies below the fair weather wave base (FA3)}

This facies association is composed of wackestones (WCK), followed by peloidal bioclastic packstones (PCK pel bio). Compared with FA1 and FA2, this facies association shows higher micritic content (Figs. 5A and 5B), suggesting sedimentation in calm water conditions, probably at greater depth. The fauna is rich in echinoids and planktonic foraminifera (Figs. 6A and 6D), which suggests that these sediments were deposited in open marine environment, probably in offshore conditions. Due the micritic content and the presence of marine bioclasts, it is assumed that this facies association was deposited by decantation in relatively deep sea conditions, probably under the action of fair weather wave orbitals (below the fair weather wave base orbitals).

\section{Reworked deposits (allochthony) (FA4)}

This facies association consists of bioclastic packstones (PCK bio) and oolitic wackestones/ packstones (WCK/PCK ool) and occurs in the contact between the Quissamã and the Outeiro formations. The combination of shallow-water diagnostic elements - like ooids and
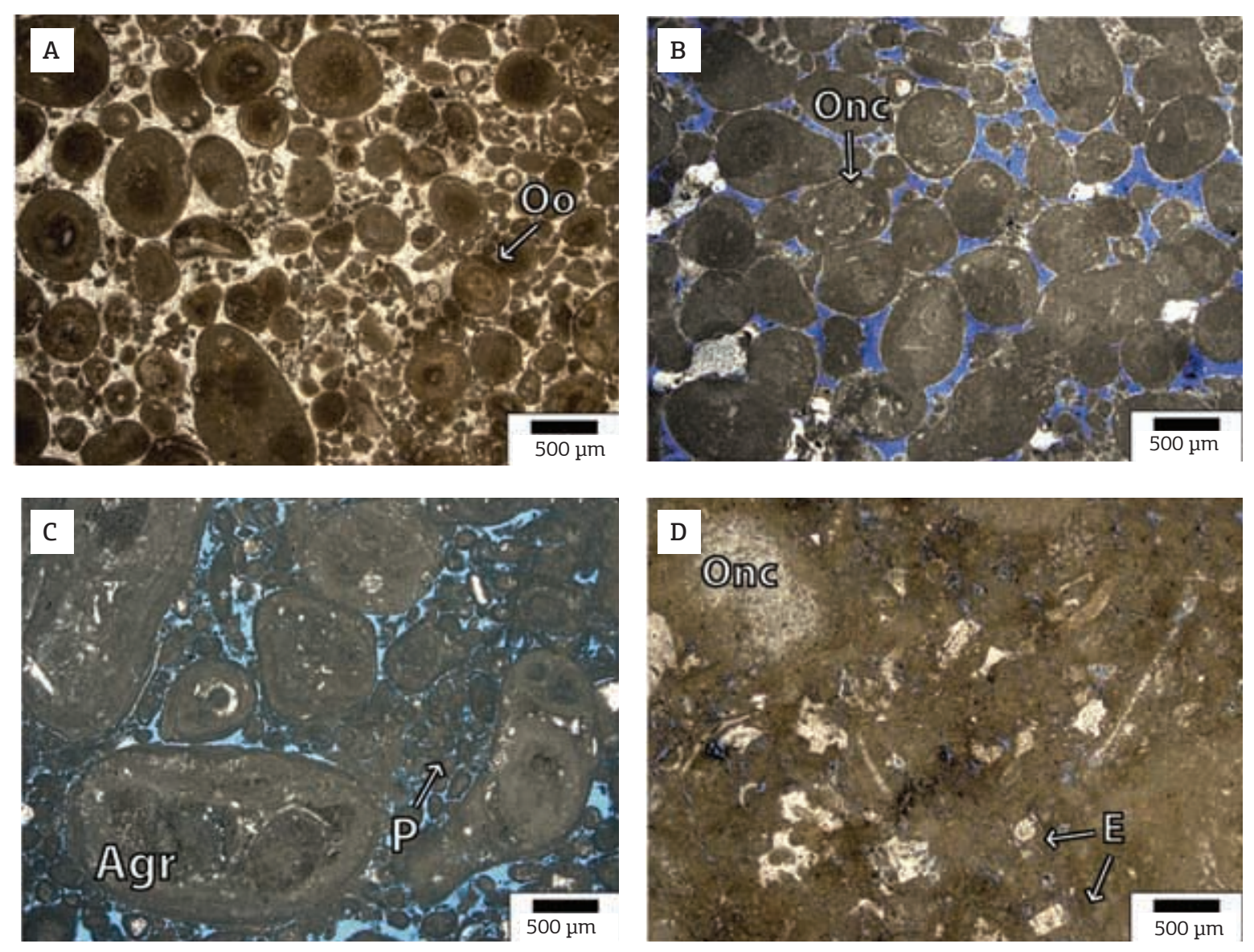

Figure 4. Photomicrographs of the facies grouped into FA1 and FA2. (A) oolitic grainstone composed of ooids (Oo), aggregate grains and peloids. The intergranular pore space was obliterated by drusy mosaic or granular cement; (B) oncolitic grainstone showing a thin fringe cement around the oncoids (Onc); (C) oncolitic peloidal grainstone exhibiting multiple granulometric sizes of aggregate grains (Agr) and peloids (P). Note the absence of cementation; (D) oncolitic peloidal packstone composed of oncoids (Onc), peloids and bioclasts of predominantly echinoids (E), sometimes showing syntaxial overgrowth 
mollusks — and deep-water diagnostic elements - as pithonelids dispersed in the matrix - is interpreted as sedimentation of allochthonous grains (Figs. 5C, 5D, $6 \mathrm{~B}$ and $6 \mathrm{C}$ ). The depositional process interpreted for these rocks involves the transport of coarse sediment from shallower to deeper areas of the carbonate platform. Two possibilities are suggested to explain this transport: rip currents and gravity flows.
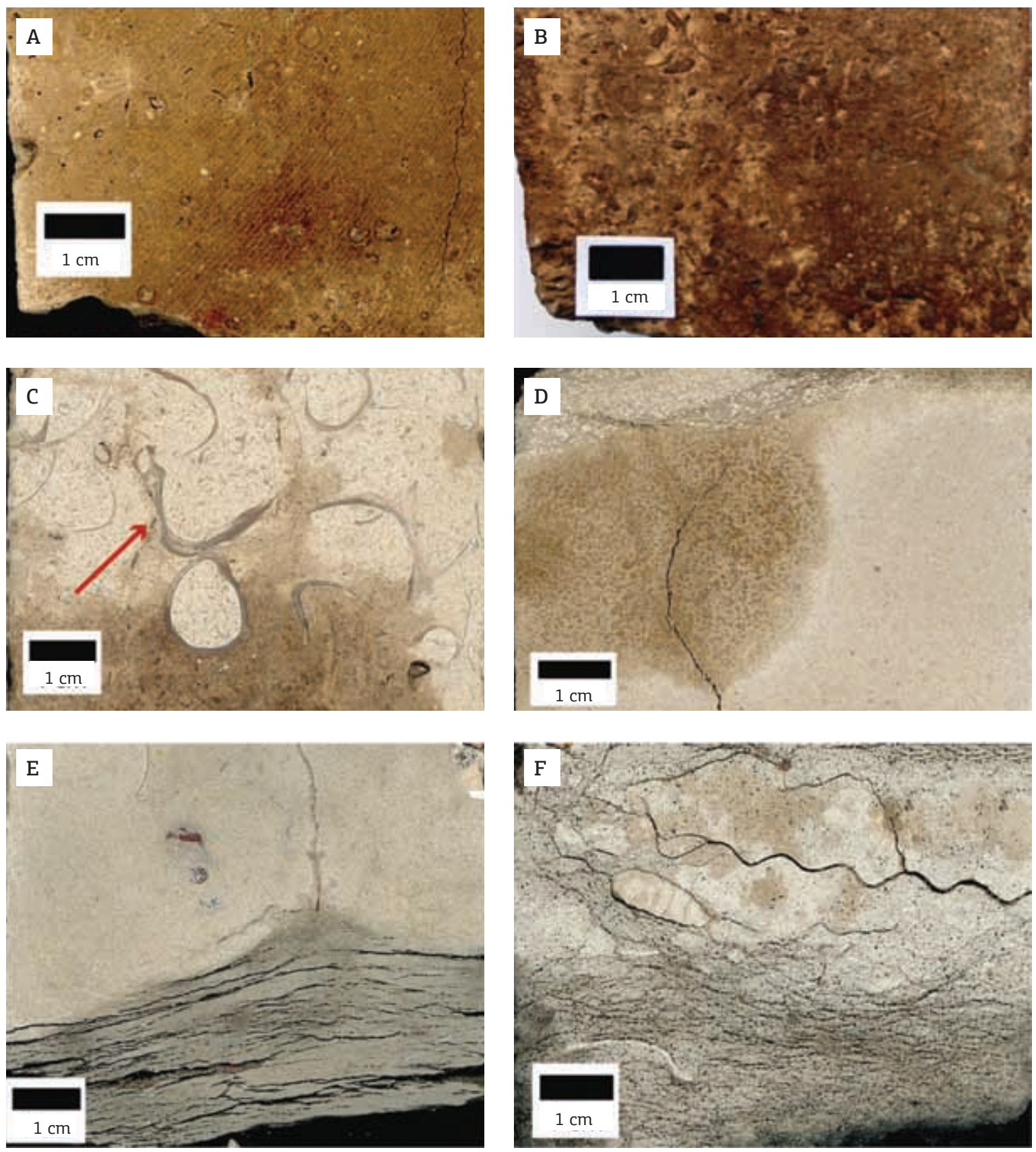

Figure 5. Facies corresponding to FA3 (A), FA4 (B and C) e FA5 (D and E). (A) peloidal bioclastic packstone, showing brownish color, mottled structure and patches of bioturbation; (B) peloidal bioclastic packstone, richer in bioclasts; (C) fragments of bivalves (red arrow) dispersed in bioclastic packstone, showing mottled structure; (D) oolitic wackestone/packstone, showing granular texture and e dark brown patches, probably due to oil saturation; (E) intercalation between pithonelids wackestone (clearer and massive/mottled) and marl (darker and laminated); (F) bioclastic wackestones. The small dark spots are glauconite grains 
Rip currents may form at the joining of the two oppositely directed longshore currents, especially during storm events in which the sea level has a momentary rise on the coast, allowing the formation of a bottom stream towards the open sea. These currents represent a unidirectional flow with enough energy to erode and transport a range
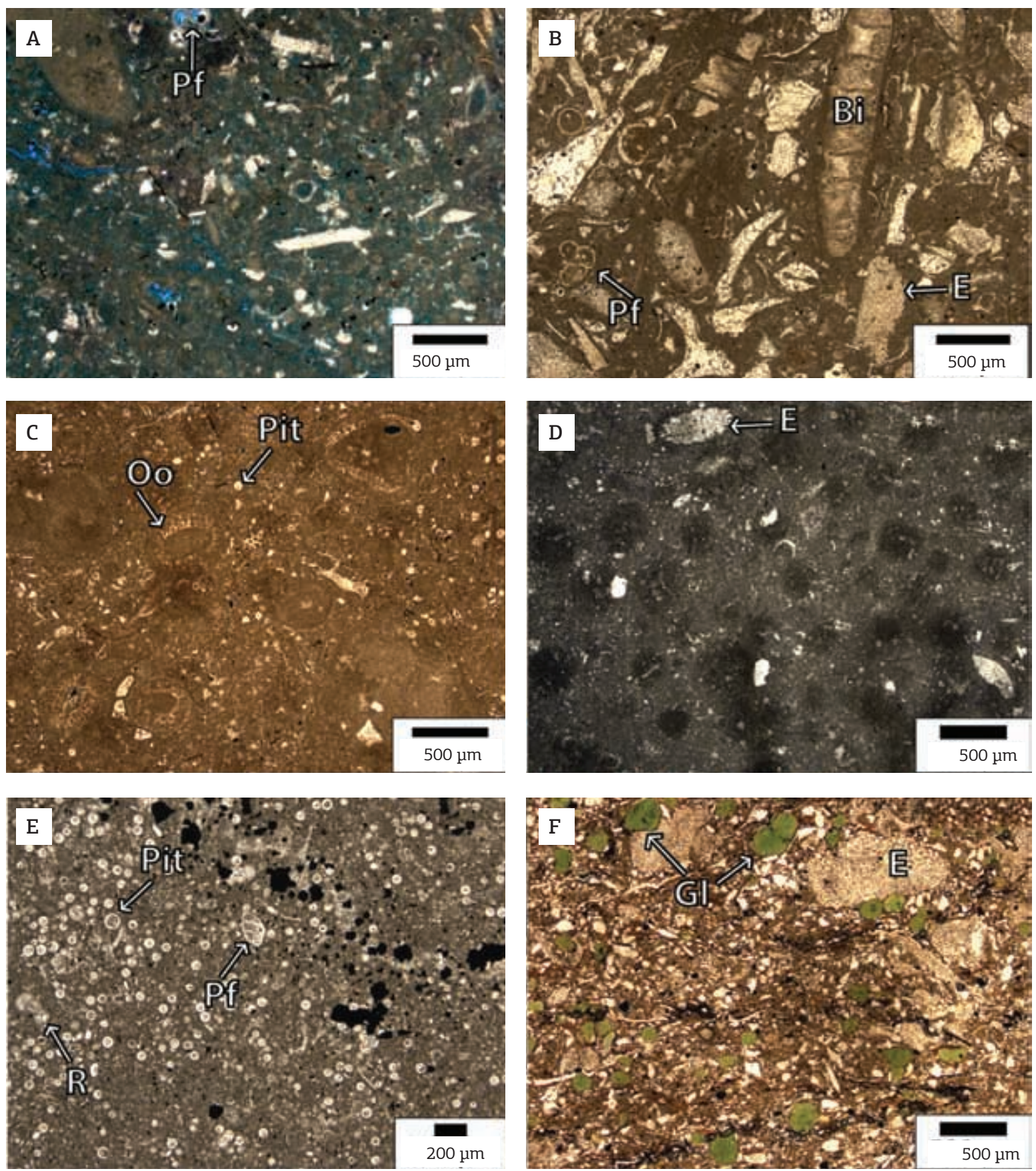

Figure 6. Photomicrographs of the sedimentary facies. (A) peloidal bioclastic packstone composed of peloids and bioclasts, as echinoids and bivalve fragments. Planktonic foraminifera (Pf) at the top of the photo; (B) bioclastic packstone showing mollusks fragments $(\mathrm{Bi})$, echinoids $(\mathrm{E})$ and planktonic foraminifera (Pf); (C) oolitic wackestone/ packstone composed of oolitic grains (Oo) and red algae dispersed in a matrix rich in pithonelids (Pit); (D) bioclastic wackestone showing echinoids (E) and siliciclastic fragments; (E) pithonelid (Pit) wackestone with some radiolarians $(\mathrm{R})$, opaque minerals and rare planktonic foraminifera $(\mathrm{Pf})$; $(\mathrm{F})$ wackestone containing siliciclastic clasts, echinoids (E) and glauconite grains (Gl) 
of sediment sizes from shoreface to offshore (Walker \& Plint 2006).

Gravitational flows (laminar regime, grain-dominated) produced during episodic events such as earthquakes and storms may explain the allochthonous characteristic of the deposits. During high-frequency cycles of rising sea level, destabilization of shallower deposits may occur, causing resedimentation of these sediments in deeper water conditions. In other words, high frequency transgressive incursions in the coast can be the trigger mechanism for mass flows.

We did not found convincing evidences leading to one or another hypothesis, such as characteristic sedimentary structures or event beds with thinning upward. Possibly, the occurrence of these facies in adjacent oil fields could contribute to a better understanding of the sedimentary processes interpreted for this facies association.

\section{Deep-water facies (FA5)}

This facies association is predominantly composed of pithonelid wackestones (WCK pit). Bioclastic wackestones with glauconite (WCK bio gl) are less frequent and occur only in the upper part of the studied interval (Outeiro Formation). The ocurrence of this micritic facies (Figs. 5E and $5 \mathrm{~F}$ ) suggests, as well as FA3, that these rocks have been formed by a decantation processes in deep and calm-water environments. The presence of pitonelids, radiolarians (Fig. 6E), and glauconite (Fig. 6F) reinforces a deeper bathymetric context that are interpreted for the FA3.

\section{DIAGENESIS}

The main processes that conditioned the diagenetic evolution of the upper part of the Quissamá Formation were: micritization, recrystallization, cementation, dissolution, dolomitization and compaction. The sequence of diagenetic events (Fig. 7) suggests the occurrence of at least four different diagenetic environments: marine phreatic, meteoric phreatic, mixing zone and burial in the eo- and mesodiagenesis.

Early eodiagenesis occurred in a marine environment with active circulating water, evidenced by an isopachous acicular fringe cement precipitated around the grains (Fig. 8A), particularly in GST onc facies. On the other hand, a marine stagnant environment (free of reworking by waves and currents) favored the micritization of grains and the formation of a micrite envelope around bioclasts (gastropods and bivalves), in various facies (Fig. 8B).

At the interface between the meteoric and marine environments, the sea water and meteoric water are mixed, resulting in low salinities, which associated with low sedimentation rates can form dolomite crystals (Longman 1980). Dolomitization (Fig. 8C) occurs in several facies (GST onc, PCK onc and WCK).

The presence of fringe and mosaic cementation, dissolution, sintaxial overgrowth and recrystallization suggest that diagenesis took place under meteoric-phreatic environment. Eodiagenesis iniciated with the precipitation of a prismatic fringe cement (Fig. 8D), mostly in the GST onc

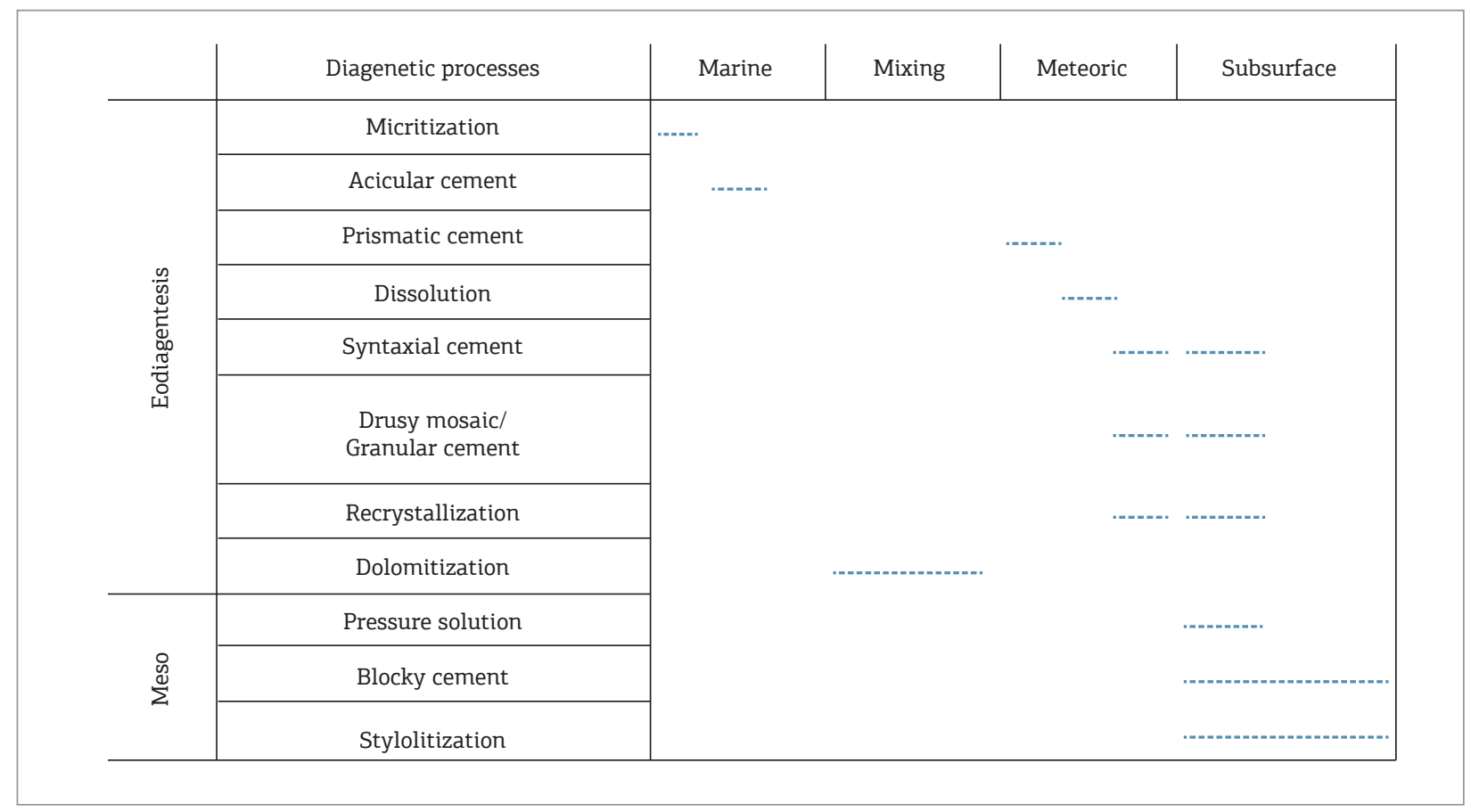

Figure 7. Relative chronology of the diagenetic processes in different environments 
facies. With the oscillation of the main sea level, the early-lithified sediment was exposed to meteoric percolation, producing molds of bioclasts and enlargement the intergranular pores (Fig. 8E).
Some of the meteoric-phreatic environment processes, as drusy mosaic or granular cementation (Fig. 8F), sintaxial overgrowth and recrystallization, may have continued to occur during early mesodiagenesis (in shallow subsurface settings).
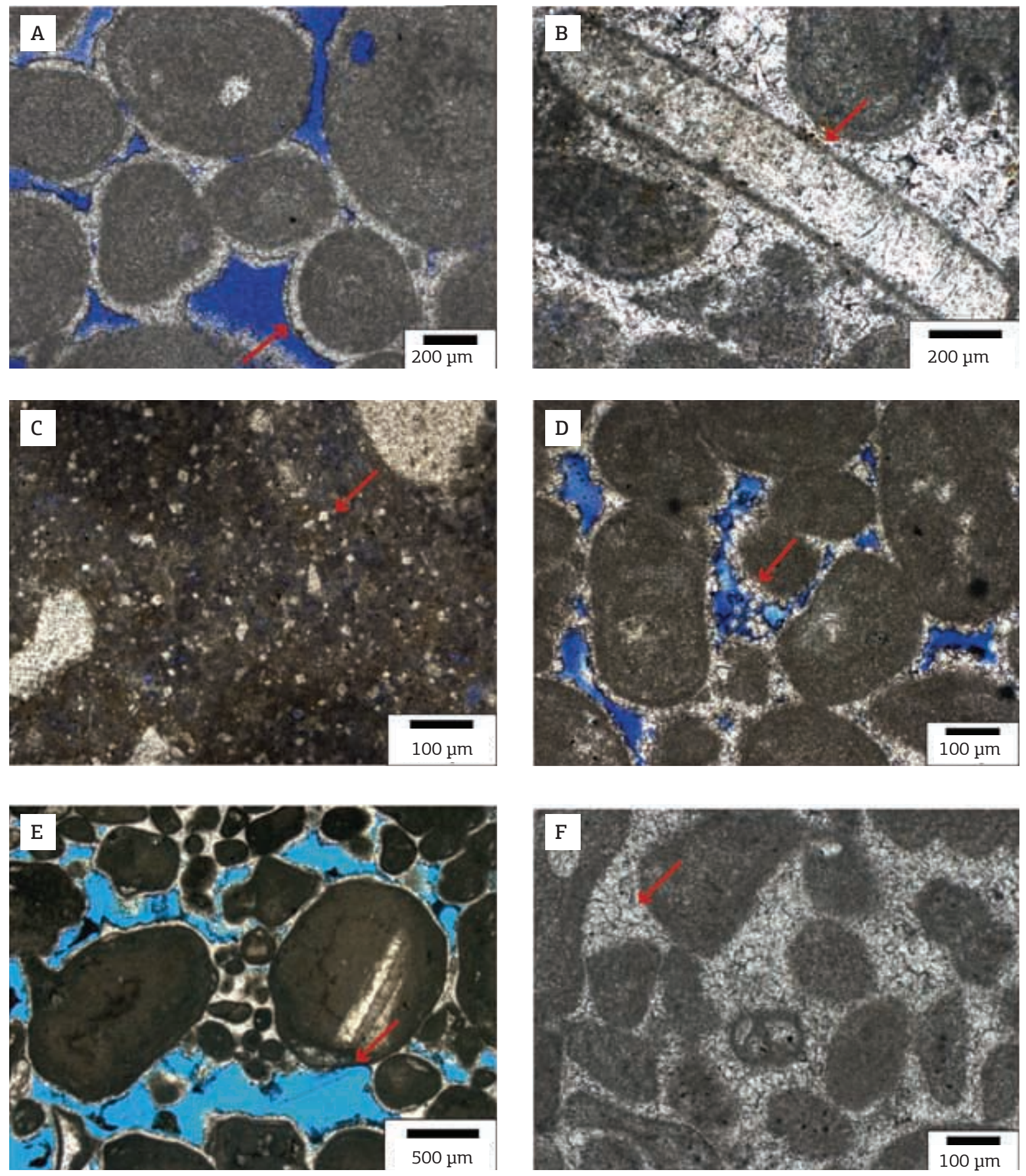

Figure 8. Diagenetic features indicative of eodiagenesis. (A) acicular isopachous fringe cement (red arrow) filling partially the intergranular pore space; (B) micritic envelope (red arrow) around bioclast; (C) partial dolomitization (red arrow) in wackestone; (D) prismatic fringe cement (red arrow) filling partially the intergranular pore space; (E) dissolution of the intergranular space (red arrow), increasing the porosity of the rock; (F) drusy mosaic or granular cement (red arrow) filling all the intergranular pore space 
When the sediment pile begins to thicken, burial conditions take place and the effect of lithostatic pressure becomes progressively more significant. During this diagenetic stage, blocky cement is produced, as well as pressure solution and stylolites. Compaction processes are evidenced by pressure solution (Fig. 9A) that evolve, progressively, to stylolitization (Fig. 9B). In cement free facies, dissolved planar contacts are formed. In facies marked by fringe-cement, the lithostatic pressure can lead to detachment of the fringe (Fig. 9C). Solutions supersaturated in $\mathrm{CaCO}_{3}$ percolate the intergranular pores during burial of the rocks and crystallize a mosaic of euhedral calcite crystals, with 100 to $200 \mu \mathrm{m}$ (Fig. 9D).

\section{VERTICAL FACIES SUCESSION AND CICLICITY ANALYSIS}

The stratal stacking pattern in the A3 and A10 wells are composed of a set of metric cycles. These cycles were defined using the concept of shallowing upward cycles (Pratt et al. 1992). In this concept, cycles are delimited at the base and at the top by planar contacts interpreted as indicative of episodic flooding surfaces, corresponding to arrangements facies interpreted as deposited under the same base level cycle in the peritidal context (Pratt et al. 1992, Einsele et al. 1991, Kerans \& Tinker 1997). The identified shallowing upward cycles correspond to the three types of hypothetical vertical succession, or ideal cycles that are illustrated in Fig. 10.

In cycles $A$ and $B$, the base of the vertical succession is represented by low-energy facies (wackestones and peloidal bioclastic packstones), evolving to moderate-energy facies of oncolitic grainstones/packstones and oncolitic bioclastic packstones, culminating in high-energy facies (oolitic and oncolitic grainstones).

Cycle $\mathrm{C}$ is distinguished from the others by the presence of pithonelid wackestones with or without glauconite, interpreted as low-energy facies, covered by allochthonous facies as bioclastic packstone and oolitic wackestone/packstone.
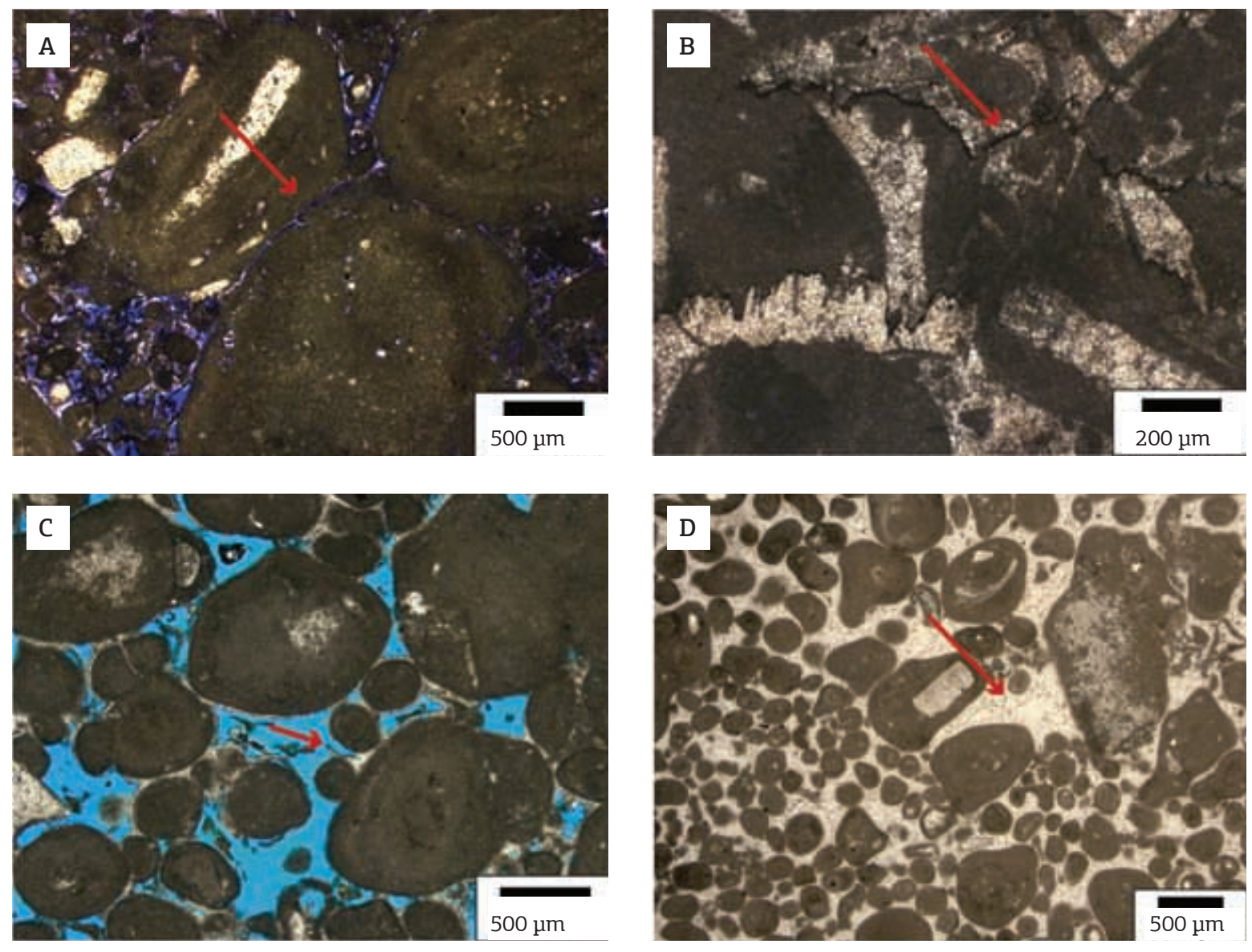

Figure 9. Diagenetic features indicative of mesodiagenesis. (A) planar contacts (red arrow) dissolved between larger grains, produced by pressure solution; (B) horizontal stylolites (red arrow), after cementation; (C) fringe cement detached from grain surface (red arrow), produced by compaction. Pores enlarged by dissolution; (D) blocky cement (red arrow) filling all the intergranular pore space 
The stacking pattern of the cycles in both wells (Fig. 11) suggests a progressively deeper environment towards the top of the succession. This interpretation is supported by the abundance of shallow-water facies (grainstones) in the basal and intermediate portions of the succession, transitioning to deep-water facies with pithonelids characteristically pelagics. Toward the top of the succession, shallowing portions of the cycles become progressively thinner, whereas deeping portions of the cycles become thicker indicating a retrogradational architecture.

The occurrence of allochthonous elements in the facies (FA4) immediately below the pelagic sedimentation containing glauconite (FA5) suggests a transgressive surface delimiting these deposits that is correlated to the beginning of drowning event in a transgressive tract, as described in the passage of the Albian to Cenomanian successions in the Brazilian Continental Margin (Koutsoukos \& Dias-Brito 1987).

\section{DEPOSITIONAL MODEL}

During the mid-Cretaceous, separation of South America and Africa plates evolved to an open ocean environment and the installation of extensive homocline carbonate ramp (Spadini et al. 1988, Dias et al. 1990). Azevedo et al. (1987) and Koutsoukos and Dias-Brito (1987), based on paleoecological analysis of foraminifera, described an Albian carbonate ramp with low gradient, characterized by large areas covered by marine water shallower than 30 meters.

The oncolitic-oolitic shoals (AF1) described here are compared to stabilized oolitic belts defined by Spadini (1992). Modern carbonate systems, such as the Bahamas, are considered analogous to Quissamã Formation carbonates, especially in terms of the geometry of the shallow carbonate banks. According to Bruhn et al. (2003), the Albian shoals have a thickness of $20 \mathrm{~m}$ and are elongated $1 \mathrm{~km}$-wide and up to $2,5 \mathrm{~km}$ long. These shoals are considered small analogs of the elongated bodies of Joulter Cays and Exumas Island in the Bahamas, with an average length of banks varying between 30 and $45 \mathrm{~km}$ in length and 10 to $15 \mathrm{~km}$ in width (Ball 1967, Grasmueck \& Weger 2002). Depositional models for Lily Bank carbonate sediments (Bahamas) reveals coarser sediments with no micrite fraction on the crests of the bars, whereas finer sediments are deposited in environments with relatively low energy as the troughs between carbonate banks (Rankey et al. 2006). This configuration suggests a direct relationship between the bathymetry, hydrodynamics energy of the environment and the grain fraction found in the different physiographic positions of the bars and oolitic shoals (Fig. 12).

The accommodation space was filled according to the depositional paleotopography, which represents a variation in the water depth inside the shoal. Between the bars and shoals crests, protected troughs were formed, allowing the deposition of GST onc pel and PCK onc bio. These facies, are characterized by enveloped grains, peloids and greater amount of micrite, related to lower energy sites. In terms of depositional energy, these sediments are equivalent to Andros Island rudstones and mud-poor packstones from Harris et al. (2015), which were interpreted as deposited in water depths ranging from 5 to 10 feet deep. These interbank regions can be compared to deposits of sandy peloidais sheets of inner platform defined by Spadini (1992), interpreted as the product of variations in depositional energy between the bank crests.

Peloidal bioclastic packstones and wackestones are associated to the deposition in low energy environments. In these
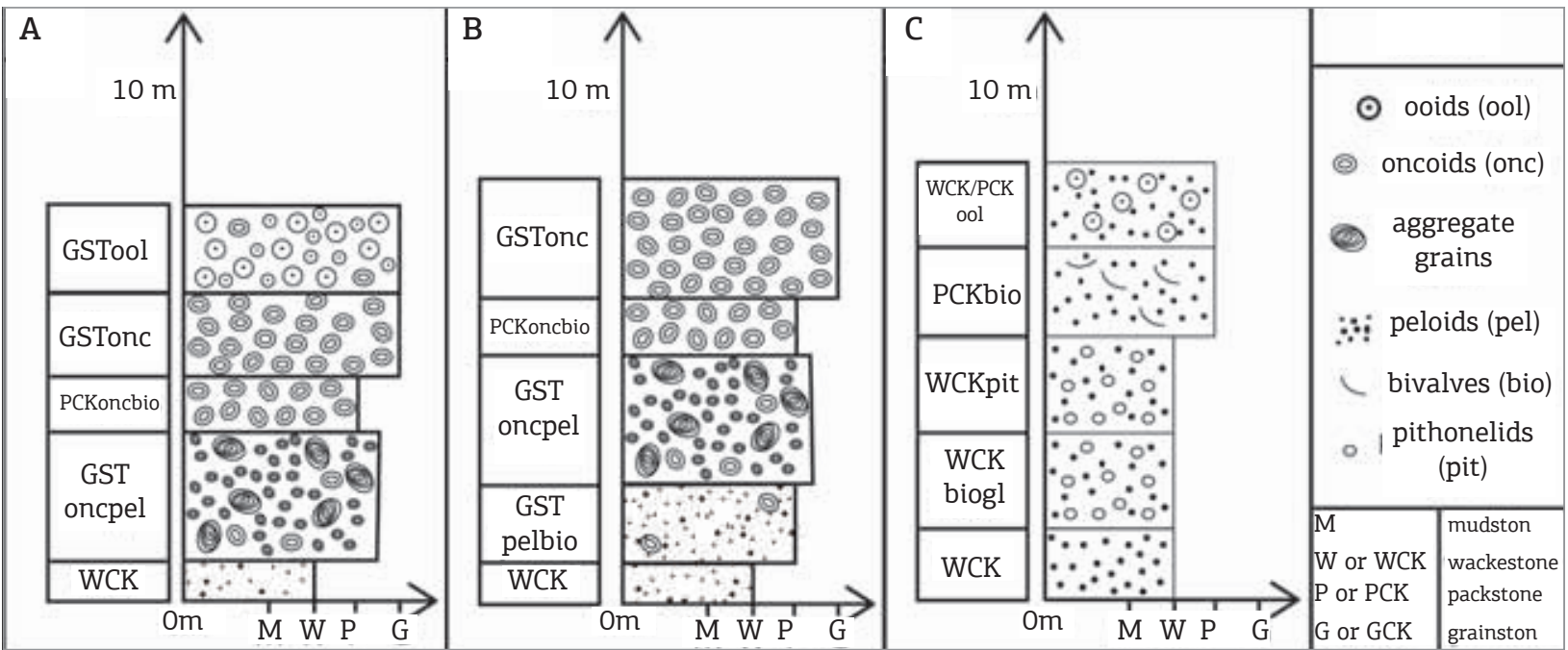

Figure 10. Ideal shallowing upward cycles interpreted for the studied succession 
facies, some foraminifera — such as the miliolids - could suggest sedimentation under hypersaline conditions, probably in confined environments such as ponds (Debenay $\&$ Guillou 2002). However, these miliolids were not found so frequently in the succession. The presence of planktonic foraminifera (Favusella washitenses), which have clearer paleoenvironmental meaning, suggests deposition in open sea conditions. From the foraminifera data available in the studied rocks, this facies association can both occur toward the open sea and toward the continent.

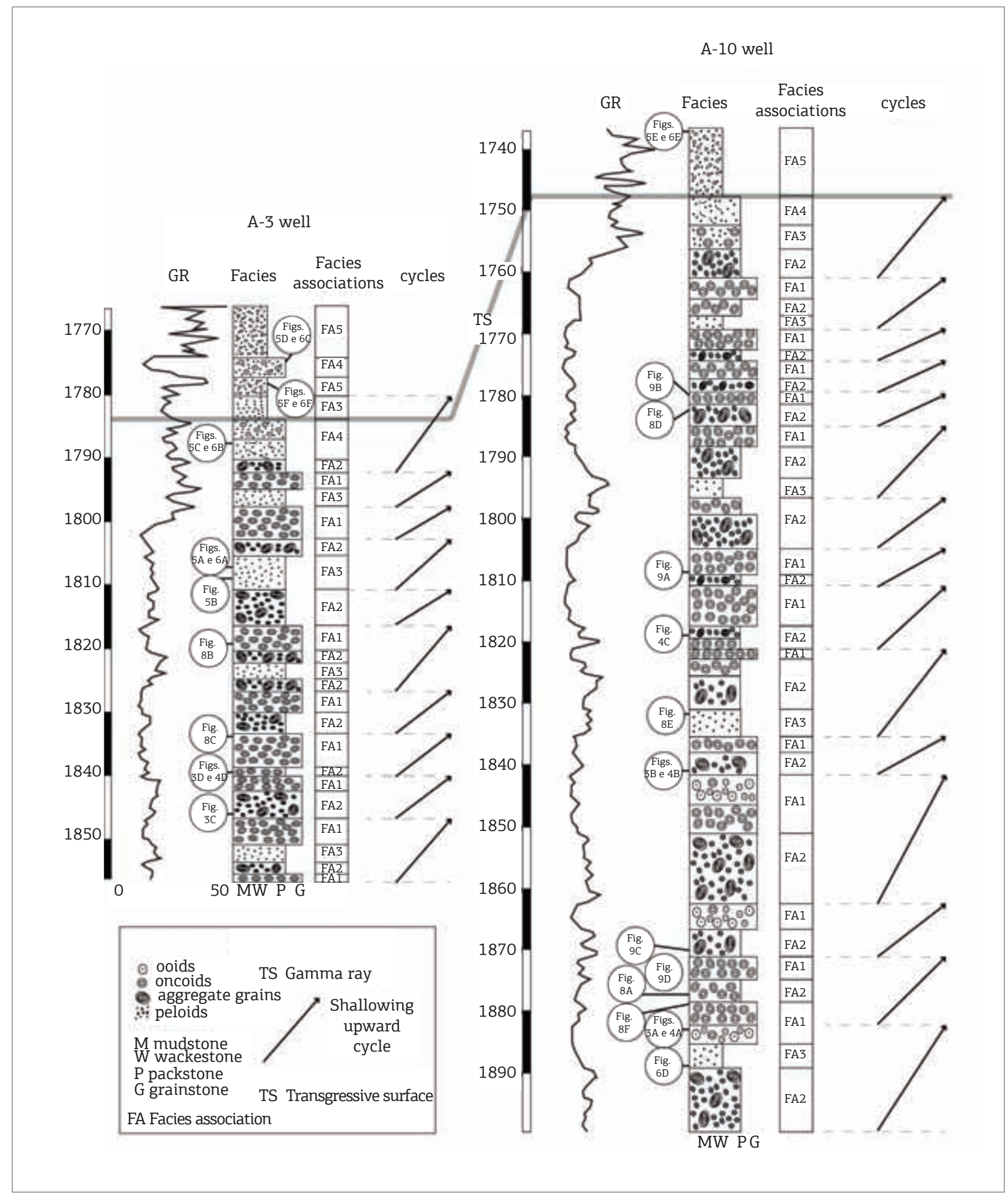

Figure 11. Columnar section evidencing the vertical stacking pattern of the shallowing upward cycles, sedimentary facies, facies associations and the location of all photos presente 
The regional drowning that marks the contact between the Quissamã to Outeiro formations reflects a particular environmental in which the allochthonous facies (FA4) was deposited. These deposits are formed by episodic pulses and are composed of reworked, rounded carbonate grains, which are deposited in offshore conditions. This process results in the deposition of a great volume of sediments containing bioclasts and ooids from proximal areas dispersed in a micritic matrix. For Gruzczynski et al. (1993), many of these shallower portions of the platform deposits are erroneously interpreted as turbidites, but they can be associated with rip currents action or subaqueous gravity mass flows.

On the other hand, as mentioned above, storm events, earthquakes and high-frequency oscillations in base level rise (Badenas \& Aurell 2001) could also destabilize shallow deposits (such as shoals), triggering non-cohesive gravitational flows (dominated by grains) and producing allochthonous deposits in deeper areas. In this context, the transgression would be interpreted as diachronous, where the deeper portions could be flooded at the same time that shoal facies are still depositing laterally in the shallower portions.

Pelagic facies, such as the FA5, correspond lithostratigraphically to Outeiro Formation and resulted from deposition in deep water, possibly in distal portions of the basin. This interpretation is supported by the occurrence of glauconite and high content of micrite in these rocks. Several studies on the occurrence of glauconite in marine environment suggest that this mineral is only formed in deep environments, which tend to have very low sedimentation rates (Odin \& Morton 1988) at depths usually between 30 and 2,000 meters (Porrenga 1967). Based on this premise, the occurrence of glauconite in Macaé Group is interpreted as a decrease in carbonate production during the drowning/ transgression of the shallow platform. Although exceptions may occur, as exemplified by Cambro-Ordovician glauconite-bearing sandstones of southwestern US (Chafetz \& Reid 2000) and the Mesoproterozoic stromatolites of China (Mei et al. 2008), the relationship between glauconite formation in marine sediments and depth must be taken with caution.

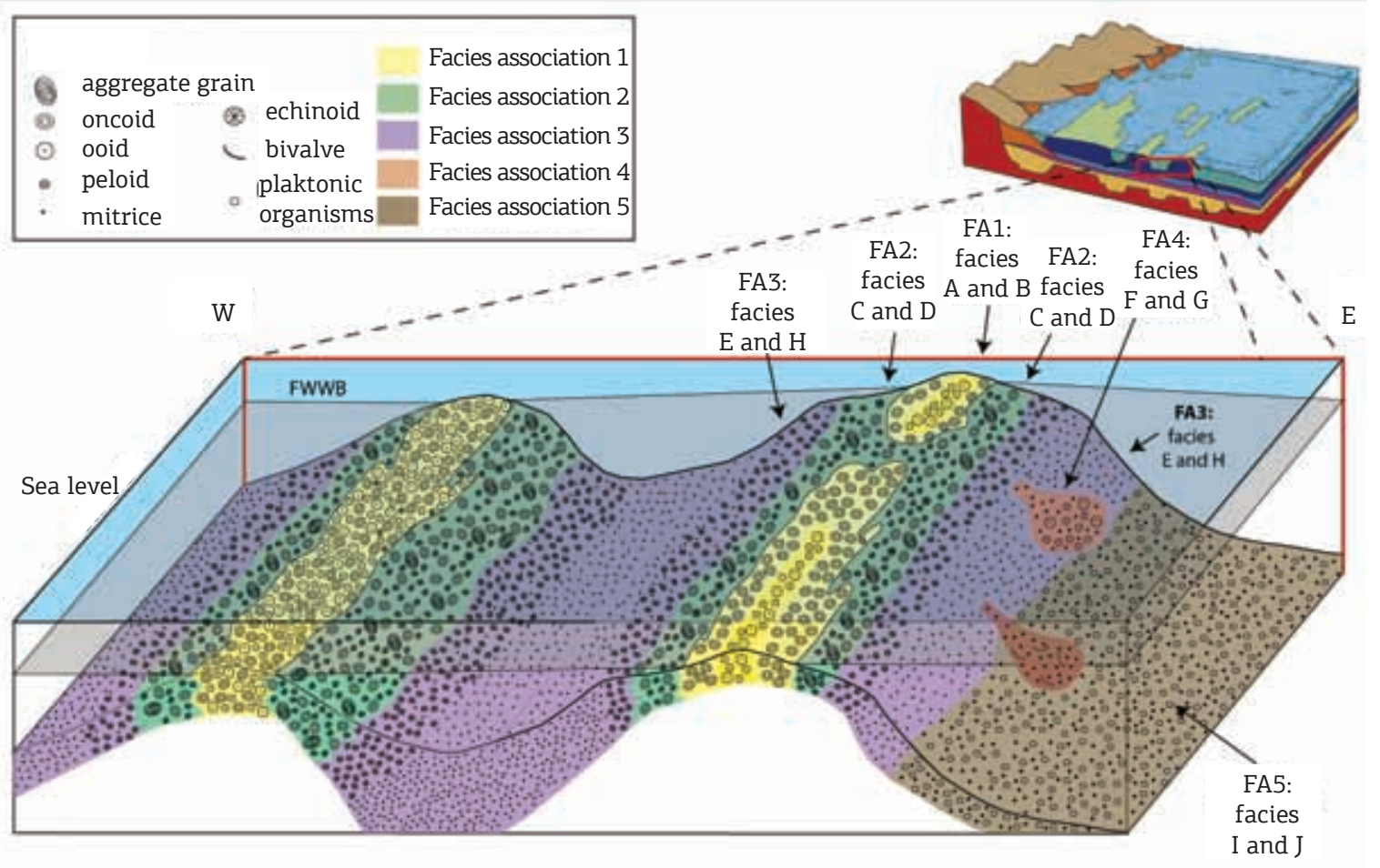

FWWB: fair weather wave base.

Figure 12. Depositional model inferred for the carbonate platform in the Campos Basin during the Albian Age. Note the physiographic position of this model compared to the scheme of Guardado et al. (1989) 


\section{CONCLUSIONS}

Macroscopic and microscopic analyses of cores from Albian carbonate rocks from the Campos Basin allowed the following conclusions to be drawn:

1. Eleven sedimentary facies occur in the studied interval, which corresponds to the upper part of the Quissamá Formation and the basal portion of the Outeiro Formation. These facies characterize sedimentation in high-energy environments (oncolitic and oolitic grainstones), moderate energy environments (oncolitic peloidal grainstones and oncolitic bioclastic packstone) and low-energy environments (peloidal bioclastic packstone and wackestone). Bioclastic packstone and oolitic wackestone/packstone occur only on the contact between Quissamá and Outeiro Formation and are considered allochthonous facies. Glauconite-bearing wackestones and pithonelids wackestones are only present in the Outeiro Formation. Dolomitized layers have a restrict occurrence;

2. Distinct depositional environments were recognized within a low slope homoclinal carbonate ramp system. Shallow carbonate shoals are composed of oolitic and oncolitic grainstones, which presents low micrite content and good to excelent esfericity and sorting. Oncolitic peloidal grainstones and oncolitic bioclastic packstones were deposited between these shoals due the energy variation associated with depositional topography. Peloidal bioclastic packstones and wackestones were formed in calm waters. The foraminiferal content did not allowed the subdivision of more specific environmental conditions. Allochtonous deposits are interpreted as episodic and considered a product of rip currents or gravity flows. Deep-water environments are related to the alternation of light gray wackestones and dark gray marls containing planktonic organisms;

3. At least three subsurface diagenetic environments can be defined. The environment of marine phreatic with active water circulation precipitated a thin isopachous fringe around the grains. Stagnant marine water environment is interpreted based on micritization of grains and the formation of micritic envelope around some bioclasts (mainly bivalves and gastropods). The meteoric-phreatic diagenesis is represented by dissolution (enlarging the intergranular pores and creating moldic porosity) and the precipitation of equigranular mosaic cement. Burial diagenesis is characterized mainly by stylolitization and blocky cementation, besides recrystallization, equigranular mosaic cement, sintaxial overgrowth, already actives in the meteoric phreatic environment. In further studies, cathodoluminescence and scanning electron microscopy investigations could contribute to the characterization of the dolomitization process, particularly in regard its origin and spatial distribution;

4. The stacking pattern of the shallowing upward cycles defined by two wells represents a progressively deeper succession toward the top of the sequence. This is indicated by shallow-water facies (grainstones) abundant in the basal and intermediate portions of the succession, passing to deep water facies with pithonelids (characteristically pelagic). The allochthnous facies (FA4) may reflect a transgressive surface, correlated to the beginning of drowning event in a transgressive system tract, as observed in the passage of the Albian to Cenomanian successions in the Brazilian Continental Margin;

5. The studied depositional model suggests a direct relationship between the variations in hydrodinamic and bathymetry and the grain size distribution of the sediments.

\section{ACKNOWLEDGEMENTS}

This work was funded by the Project "Field A" UNESP/ PETROBRAS. The authors would like to thank the Postgraduate Program in Regional Geology, Universidade Estadual Paulista (UNESP) and Centro de Geociências Aplicadas ao Petróleo (UNESPetro). We also want to thank the Unidade Operacional - Bacia de Campos (UO-BC/Petrobrás), for granting access to the studied cores and thin sections.

\section{REFERENCES}

Azevedo R.L.M., Gomide J., Viviers M.C. 1987. Geo-história da Bacia de Campos: do Albiano ao Maastrichtiano. Revista Brasileira de Geociências, 17(2):139-146.

Badenas B. \& Aurell M. 2001. Proximal-distal facies relationships and sedimentary processes in a storm dominated carbonate ramp (Kimmeridgian, northwest of Iberian Ranges, Spain). Sedimentary Geology, 139:319-340.

Ball M.M. 1967. Carbonate sand bodies of Florida and the Bahamas. Journal of Sedimentary Petrology, 37:556-591.
Bathurst R.G.C. 1971. Carbonate sediments and their diagenesis. Developments in Sedimentology, 620 p.

Bruhn C.H.L., Gomes J.A.T., Lucchese C.D., Johann P.R.S. 2003. Campos basin: reservoir characterization and management - Historical overview and future challenges. In: Paper OTC 15220 presented at the Offshore Technology Conference, Houston, Texas: 14 p.

Chafetz H.S. \& Reid A. 2000. Syndepositional shallow-water precipitation of glauconitic minerals. Sedimentary Geology, 136:29-42 
Dahanayake K. 1978. Sequential position and environmental significance of different types of oncoids. Sedimentary Geology, 20:301-316.

Debenay, J.P. \& Guillou, J.J. 2002. Ecological transitions indicated by foraminiferal assemblages in paralic environments. Estuaries, 25:1107-1120

Dias J.L., Scarton J.C., Esteves F.R., Carminatti M., Guardado L.R. 1990. Aspectos da evolução tectono-sedimentar e a ocorrência de hidrocarbonetos na Bacia de Campos. In: Raja Gabaglia G.P. \& Milani E.J. (Coords.) Origem e evolução de Bacias Sedimentares. Rio de Janeiro, PETROBRAS: p. 333-360.

Dias-Brito D. 1982. Evolução paleoecológica da Bacia de Campos durante a deposição dos calcilutitos, margas e folhelhos da Formação Macaé (Albiano e Cenomaniano). Boletim Técnico da Petrobras, 25(2):84-97.

Dunham R.J. 1962. Classification of carbonate rocks according to depositional texture. In: Ham, W.E. (Ed.) Classification of carbonate rocks. Tulsa: American Association of Petroleum Geologists, Memoir 1: p. 108-122.

Einsele G., Ricken W., Seilacher, A. 1991. Cycles and Events in Stratigraphy. Springer-Verlag, p. 955 p.

Embry A.F. \& Klovan J.E. 1971. A Late Devonian reef tract on northeastern Banks Island, N.W.T.. Bulletin of Canadian Petroleum Geology, 19:730-781.

Esteves F.R., Spadini A.R., Saito M. 1987. A sedimentação alboturoniana (Formação Macaé) da Bacia de Campos. In: Anais do I Simpósio de Geologia Regional RJ-ES, v.1, p. 27-42.

Falkenhein F.U.H., Franke M.R., Carozzi A.V. 1981. Petroleum Geology of the Macaé Formation (Albian-Cenomanian), Campos Basin, Brazil (carbonate Microfacies-depositional and Diagenetic Models-natural and Experimental Porosity). Petrobrás, CENPES, Ciência Técnica Petróleo, Seção Exploração Petróleo, v. 11, 140 p.

Franz E.P. 1987. Análise da geologia de reservatório dos carbonatos da Formação Macaé no campo de Enchova, Bacia de Campos. MS Dissertation,, Universidade Federal de Ouro Preto, 135 p.

Guardado L.R., Gamboa L.A.P., Lucchesi C.F. 1989. Petroleum Geology of the Campos Basin, Brazil, a Model for a Producing Atlantic Type Basin. In: Edwards J.C. \& Santogrossi P.A. (Eds.) Divergent/Passive Margin Basin. Tulsa, AAPG Memoir 48, p. 3-79.

Guimarães M.M. 1994. Caracterização geológica e geoestatística de reservatório carbonático da Bacia de Campos. MS Dissertation, Instituto de Geociências, Universidade Estadual de Campinas, 147 p.

Grasmueck M. \& Weger R. 2002. 3D GPR reveals complex internal structure of Pleistocene oolitic sand bar. The Leading Edge of Exploration, 21:634-639.

Gruszczynski M., Rudowski S., Semil J., Slominski J., Zrobek J. 1993. Rip currents as a geological tool. Sedimentology, 40:217-236.

Harris P.M.M., Purkis S.J., Ellis J., Swart P.K., Reijmer J.J.G. 2015. Mapping bathymetry and depositional facies on Great Bahama Bank. Sedimentology, 62(2):566-589.

Koutsoukos E.A.M. \& Dias-Brito D. 1987. Paleobatimetria da margem continental do Brasil durante o Albiano. Revista Brasileira de Geociências, 17:86-91.
Kerans C. \& Tinker S.W. 1997. Sequence stratigraphy and characterization of carbonate reservoirs. Society of Economic Paleontologists and Mineralogists, Short Course Notes, 40, 165 p.

Longman M.W. 1980. Carbonate diagenetic textures from nearsurface diagenetic environments. American Association of Petroleum Geologists Bulletin, 64(4):461-487.

Mei M., Yang F., Gao J., Meng Q. 2008. Glauconites formed in the highenergy shallow-marine environment of the Late Mesoproterozoic: case study from Tieling Formation at Jixian Section in Tianjin, North China. Earth Science Frontiers, 15(4):146-158.

Milani E.J., Brandão J.A.S.L., Zalán P.V., Gamboa L.A.P. 2000. Petróleo na margem continental brasileira: geologia, exploração, resultados e perspectivas. Revista Brasileira de Geofísica, 18(3):351-396.

Odin G.S. \& Morton A.C. 1988. Authigenic green particles from marine environments. In: Chilingarian G.V. \& Wolf, K.H. (Eds.). Diagenesis, vol. II. Elsevier, Amsterdam, p. 213-264.

Ojeda H.A.O. 1982. Structural framework, stratigraphy, and evolution of Brazilian marginal basins. American Association of Petroleum Geologists Bulletin, 66:732-749.

Ponte F.C. \& Asmus H.E. 2004. As bacias marginais brasileiras: estágio atual de conhecimento. Boletim de Geociências da Petrobras, 12(2):385-420

Porrenga D.H. 1967. Glauconite and chamosite as depth indicators in the marine environment. Marine Geology, 5/6:495-501.

Pratt B.R., James N.P., Cowan C.A. 1992. Peritidal Carbonates. In: Walker R.G. \& James N.P. (eds.). Facies Models: response to sea level changes. Geological Association of Canada, p. 219-238.

Rankey E.C., Riegl B., Steffen K. 2006. Form, function and feedbacks in a tidally dominated ooid shoal, Bahamas. Sedimentology, 53:1191-1210.

Simone L. 1980. Ooids: a review. Earth Science Review, 16:319-355.

Spadini A.R. 1992. Processos deposicionais e ciclicidade em carbonatos albianos da plataforma rasa da Bacia de Campos. MS Dissertation, Instituto de Geociências, Universidade Federal do Rio de Janeiro. Rio de Janeiro, 143 p.

Spadini A.R., Esteves F.R., Dias-Brito D., Azevedo R.L.M., Rodrigues R. 1988. The Macaé Formation, Campos basin, Brazil: Its evolution in the context of the initial history of the South Atlantic. Revista Brasileira de Geociências, 18(3):261-272.

Walker R.G. 1992. Facies, facies models and modern stratigraphic concepts. In: Walker R.G. \& James N.P. (Eds.) Facies models: response to sea level change. Geological Association of Canada, 1992. p. 1-14.

Walker R.G. \& Plint A.G. 1992. Wave and storm-dominated shallow marine systems. In: Walker R.G. \& James N.P. (Eds.) Facies models: response to sea level change. Geological Association of Canada, p. 219-238.

Winter W.R., Jahnert R.J., França A.B. 2007. Bacia de Campos. Boletim de Geociências da Petrobras, 15:511-529.

Arquivo digital disponível on-line no site www.sbgeo.org.br 